\title{
Listening to Labor
}

\author{
Michael Curtin and Kevin Sanson
}

At a time when anyone can be a producer, creator, or YouTube performer, we nevertheless spend more hours watching professionally produced feature films and television programs than ever before. We are also awash in media coverage of movie premieres, television finales, celebrity gossip, box office data, TV ratings, and social media metrics. Although some critics contend that we are currently experiencing a dramatic democratization of media forms, audiences remain enamored with "traditional" mass media and the seemingly creative and enchanting environs of Hollywood. Indeed, peeking behind the screen is a foundational component of entertainment news and variety shows, featuring interviews with marquee talent who offer insights about the artistic choices and backstage antics that have shaped some of our favorite entertainments. We may live in an era increasingly dominated by do-it-yourself media, but our fascination with top-line talent endures.

Behind the glitz and glamour, however, offscreen workers invest untold hours crafting scripts, designing costumes, and rigging sets. They also conjure up mesmerizing special effects and manage the mind-boggling logistics of production. Much of their work is organized according to industrial principles that economize at every step in a sprawling creative process, constantly seeking efficiencies and accelerating workflows. Although strategic decisions are made on studio lots in Southern California, the labor process now extends across a vast network of production hubs in the United States, Canada, and Europe, among other locales. Indeed, Hollywood now employs a global mode of production run by massive media conglomerates that mobilize hundreds, sometimes thousands, of workers for each feature film or television series. Yet these workers and their labor remain 
largely invisible to the general audience. In fact, this has been a signal characteristic of Hollywood style for more than a hundred years: everything that matters happens on-screen, not off. Consequently, when it comes to movies and television, the voices heard most often are those belonging to talent and corporate executives. Those we hear least are the voices of labor, and it's that silence that we aim to redress in the following collection of interviews.

Of course this void isn't unique to Hollywood or to the United States. In most parts of the world and in most industries, expressions of pride, aspiration, or frustration from laborers about their working lives are rarely the subject of much attention. It was therefore striking that WCFL, a pioneer of early radio, sought to overcome this deficit when it took to the airwaves in 1926 as the "Voice of Labor." Inspired and funded by a federation of Chicago labor unions, the station thrived in the face of intense adversity before succumbing to commercial pressures and a right-wing political backlash during the late 1940s. ${ }^{1}$ Interestingly, Studs Terkel—an activist actor, author, and raconteur who was blacklisted during the "red scare"embraced this legacy when he joined another Chicago radio station and launched one of the most legendary careers in American broadcasting. He did so by listening, and listening intently, to everyday stories about jobs, lifestyles, and entertainment but also about racism, housing, and migration. His radio interlocutors proved so eloquent that during the late 1950 s a national publisher encouraged him to edit and publish transcripts of his conversations, which led to a string of books, some of them best-sellers, one of them a Pulitzer Prize winner.

Most beguiling was a 1974 book with a simple title, Working, and a deceptively mundane subtitle, People Talk About What They Do All Day and How They Feel About What They Do. ${ }^{2}$ In dozens of interviews the book offers a broad cross section of voices that include a miner, a secretary, a farmworker; a banker, a waitress, a cabbie; a pianist, a welder, and a washroom attendant. Probing gently but persistently, Terkel reveals their respective desires to make meaning out of everyday toil, to turn even an ordinary task into a craft that reveals something about them, their workplace, and the social order. Over the course of Terkel's career, he developed an interview style that mixed journalistic and ethnographic research techniques. Yet rather than focusing on celebrities, elites, or exotics, Terkel spent most of his time systematically exploring the lives and imaginations of everyday Americans. He also probed the memories of his subjects, allowing their quotidian recollections of major events like Pearl Harbor and the civil rights movement to enter the pages of written history. In the process Terkel became a pioneer in the emerging field of oral history.

Inspired by such earlier efforts to document the voices of labor, we set out to listen to the craft secrets and "war stories" of the Hollywood workforce. ${ }^{3}$ Our interview sessions unfolded organically, each beginning with an account of professional duties as well as the daily challenges and satisfactions of working on a 
sprawling creative endeavor. As we heard time and again, success in such ventures is measured as much by what goes unnoticed as by what is. Each frame of a feature film or television show is filled with eloquent but inconspicuous traces of craft. For example, costumes convey a range of character traits and relationships, and are fashioned to harmonize with sets, props, and cinematography. Likewise, a seemingly simple shaft of illumination that backlights a sea of parishioners shines down from a complex lighting rig erected outside a church window, requiring the nimble and collaborative efforts of electricians, grips, and lighting technicians.

Unlike an integrated assembly line, motion picture production is a large-scale industrial enterprise that is distinguished by the collaborative production of prototypes, each one the outcome of thousands of creative choices. ${ }^{4}$ Movies are made, not mass produced. They are the product of seemingly endless tinkering and deliberation that begins each morning at sunrise and often extends late into the night. Microphones, cameras, and props are positioned and repositioned, angles are tweaked, sound levels are mixed and monitored. A remarkable collection of skills are brought to bear throughout the workday, requiring self-discipline and sociality that are, we found, a source of enormous pride among craft workers and crew, and a baseline requirement for future employment.

This social dimension of labor operates at other levels as well. A costume designer not only visualizes character traits and color composition but also invests hours of affective labor, helping marquee talent to model and approve outfits that will satisfy their on-screen roles and offscreen personae. A makeup artist-the very first person to work with an actor each day-must also manage each performer's professional concerns and personal sensitivities, sometimes playing the role of confidante and therapist while also crafting a countenance that will be projected across millions of screens, large and small, often in unsparing close-up.

But even before the camera is uncapped, thousands of collaborative calculations are made as well in writers' rooms and production meetings. Sets are designed, materials marshaled, and seemingly inconsequential items are flown in from afar. Location permits and government approvals are secured, making it possible to shoot a chase scene through a sleepy suburb or down a crowded city street. Even more daunting, many feature films and television shows that are conceived in Hollywood are executed in locations around the world, requiring a mammoth amount of organizing to pull together the people and equipment necessary for each project. Again, sociality and professionalism are at a premium. Production managers fashion flexible networks, routines, and protocols that allow them to accommodate the disparate demands of each production while also maintaining a reputation for consistency and cost management.

As each project moves into the postproduction phase, sound effects and music tracks are insinuated into the footage, providing yet another subtle layer of craft labor. And perhaps the most remarkable trend in postproduction since the 1990 s is 
the growing prominence of visual effects, which may involve eye-popping flights of visual fantasy or the delicate refashioning of recorded images. In the most extreme cases, actors perform in front of a studio green screen, which is then replaced by computer-generated imagery, a painstaking endeavor that involves months of labor by hundreds of visual artists and technicians working in shops around the world. In other cases the visual effects are less spectacular but still pervasive: hairlines are reshaped, pimples removed, complexions recolored. This postproduction labor is broken down into thousands of specialties and assignments. And although staff members gather regularly to critique footage and coordinate tasks, most of the work is quite solitary, requiring protracted and meticulous toil over the delicate contours of a whisker or a snowflake.

One of the most striking aspects of these interviews is the recurring commentary on the pleasures of craft, the opportunity to recount a creative solution or to describe a project that succeeded against all odds. We took these as both expressions of satisfaction and as performances of expertise. Working from project to project, which is now common in the motion picture industry, requires a cultivated capacity for self-promotion that spills beyond the workplace, even into the context of an interview session where one is invited to reflect deeply about a job that is fraught with harried deadlines and demands. Still, it would be cynical to suggest that self-promotion is the only or even the primary motivation for this pattern of responses. Aesthetic pleasures, sociality, and creative theorizing resonate throughout these interviews because they seem to represent the baseline satisfactions that motivate workers to accept the taxing demands of motion picture production. ${ }^{5}$

Yet despite this passion and resilience, our interlocutors also expressed exasperation with a system that increasingly undermines their ability to do what they are hired to do. With each passing year, they see more obstacles, hurdles, and hindrances standing in the way of a job well done. Unlike the halcyon days of the Hollywood studios, the "genius of the system" seems to be taking a turn toward madness. ${ }^{6}$ The movie business today is producing bigger and more spectacular amusements but at the same price point as last year's model, and in less time. Foot to the pedal, the industry is careening along under conditions that many deem unsustainable, with significant implications for the future sustainability of its global production apparatus, and even more dire consequences for the personal and professional lives of media workers.

\section{THE MUTABLE MATRIX OF MEDIA LABOR}

In 2010, the Media Industries Project at the University of California commenced a round of meetings and interviews with industry personnel at all levels of the Hollywood hierarchy. ${ }^{7}$ Conversations ranged broadly, but time and again, they spontaneously drifted toward two controversial trends that have profoundly 
transformed the motion picture business over the past thirty years: corporate conglomeration and globalization. Eventually these issues became the focus of a multifaceted research project and the subject of a collection of scholarly essays entitled Precarious Creativity: Global Media, Local Labor (2016). ${ }^{8}$ Working with colleagues from around the world, we developed a critical framework for recasting debates about media labor around the concepts of precarity and creativity under a globalized regime of industrial production. This companion volume, Voices of Labor: Creativity, Craft, and Conflict in Global Hollywood, builds on the critical insights of its predecessor but also plies fresh terrain by encouraging readers to think more specifically about the nature of craft labor as it is refigured in the context of a highly mobilized mode of media production.

Drawing from the detailed and personal accounts in this collection, we offer three interrelated propositions about the current state and future prospects of craftwork and screen media labor:

1. Craftwork exists within an intricate and intimate matrix of social relations.

Historically, craftwork in the film and television industries has been characterized by a detailed division of skilled labor designed to improve workflow efficiencies and productivity. ${ }^{9}$ Although instigated by studio managers, many labor organizations and craft workers embraced this system of distinctions because it allowed them to hone their skills and establish a sense of creative identity, pleasure, and pride while nevertheless working in an industrial setting. Craft identities fostered standards of excellence and achievement within each job category, and they provided a context for workers to pursue recognition from managers and colleagues.

Even writers, directors, and actors have adopted craft identities despite the fact that many of them enjoy profit participation and outsize creative influence. In industry parlance, they are considered above-the-line talent, versus the craft and services employees who are paid only wages and benefits. ${ }^{10}$ Creative elites adopted craft identities partly because of the privileges and protections that unionization afforded them. But it also was a consequence of the American legal system, which has allocated authorial prerogatives to the corporate studios, relegating top-line talent-like their below-the-line counterparts-to the status of "work for hire."11

On the other end of the spectrum, service workers are not technically considered creative employees, but many have come to perceive and represent their work as craft-like, since it has become the marker of status and value throughout the industry. Craft also served as the most pervasive principle for labor organizing during the 1930s when actors, set dressers, and carpenters each aligned themselves with unions or locals that were identified with particular job categories. Moreover, craft has served the interests of the major studios, since it elevated the status of a commodity art form by fostering an aura of innovation throughout the workplace.

This structured sociality of screen media production has fostered a rich history of solidarity and collective identity among the workforce, and distinguishes craftwork from its corollary on the factory assembly line. And yet, most scholarly accounts fail to capture the sheer intricacy and intimacy of relationships among 
motion picture workers. Remarkably, this aspect bubbles to the surface throughout the following interviews: screen media labor operates within a complex matrix of social relations that are iterative, mutable, and contingent. Static conceptions of class relations between management and labor-or even between producer, talent, and crew-simply fail to appreciate these elaborate social ties or the ways in which they are changing in the current era of corporate conglomeration and globalization.

Film and television production today requires the logistical coordination of a colossal but capricious roster of people, places, and institutions. Workflow schedules and productivity pressures emanate from distant corporate and financial headquarters, while the actual labor of moviemaking now unfolds across expansive spatial terrains, sometimes taking place in multiple locations at once. In the midst of this spiraling complexity, every single person we interviewed talked about the extended web of relationships they must sustain with producers, colleagues, and assistants but also, in some cases, with local residents, business owners, public servants, and even national security officials.

2. Hollywood craftwork today constitutes a regime of excessive labor.

We furthermore learned that this highly socialized mode of production has engendered forms of labor rarely associated with craft and crew: soothing an actor's ego; sharing childcare duties; appeasing a disgruntled resident; lobbying disinterested politicians; supervising safety concerns; coordinating logistics in multiple languages; moving to a new location (again and again) to find work. These stories are the largely undocumented social realities of media labor today-the hidden, voluntary, unrecognized, and often unwaged aspects of craftwork.

Many of our interlocutors are now accountable for a range of affective, logistical, and legal duties that stretch well beyond the parameters of the studio or the conventional time clock. Productions are bigger, responsibilities are burgeoning, and workdays are longer, yet budgets are tighter and deadlines are shorter. Time away from home is growing longer, as are supply lines, so that quality resources are often difficult to secure. At the same time, workplace protections are weaker, jobs are scarcer, and frustrations are more visible. And still, pride in a job well done remains an enduring source of pleasure for craft workers, perhaps an even more powerful point of satisfaction because it has been realized under such trying circumstances.

In this context, the notion of excess indexes the persistent pressure for "more" in the workplace, which is a consequence of equally excessive structural change that stems from the concentration of corporate power, the financialization of creativity, the proliferation of far-flung production hubs, and the escalating impact of production subsidies. Many of our interlocutors, especially the more experienced and senior ones, conveyed a sense of resignation about these developments, saying they simply "check out" when the pressures grow too intense. If they need a respite from many months on the road, they simply pass on job offers while they take time to recharge. Some veterans have pulled back more dramatically, restricting themselves to employment opportunities that pay less but keep them closer to home. Others have 
left the industry entirely because of health and wellness concerns. Overall, veterans sense a pattern of decline, not just in workplace conditions and compensation, but also in the ineffable satisfactions of the job. In an off-the-record conversation, one person confided, "I get the sense that no one seems to be having fun anymore."

Although most of our interlocutors grudgingly accept this regime of excessive labor as somehow inevitable, they seem well aware that the escalating demands and general conditions of craftwork have become increasingly pernicious and potentially ruinous, affecting both their personal welfare and their creative capacities. Everyone in some fashion questioned the relentless grind, and acknowledged that it favors a particular kind of worker: young, single, and mobile. Even the most junior employees spoke with some nostalgia for a bygone era when work was consistent, mentorship was an ingrained aspect of the job, and the respect for the craft seemed more palpable. Rather than seeing themselves as career employees with a growing wealth of experience, most worry about how much longer they can stay in the game and stay creative, given the current trends.

3. Screen media production is a protean entity.

The factory assembly line is a residual concept of an earlier era of industrialization when capital was understood as a fixed cost that was anchored in place. The productivity and dynamism of the assembly line was derived from the relentless adaptation of processes within the factory that involved swapping out inputs, recalibrating machinery, or redeploying the workforce. The signature feature of fin-de-siècle globalization was for manufacturers to extend these principles beyond the bounds of the factory and the nation-state, creating a global assembly line.

Yet the regime of excessive labor outlined above represents what we consider a distinctive phase of flexible capitalism in the screen media industries, since it is characterized by a mobile regime of socio-spatial relations that entails a more protean mode of production, one that involves a constant refashioning of relations and resources across locations, all the while sustaining a fiction of functional continuity. This is not to say that the motion picture business has entirely turned the page. Remnants of the studio system's integrated and detailed division of labor remain, providing templates for adaptations that now take place at multiple junctures. But these templates are largely symbolic, given new corporate strategies that are increasingly untethered from the exigencies of place.

Today, the persistent resocialization and respatialization of production makes for a much more nimble structure, one that can accommodate incidents anywhere in the system, like a policy change or a tragic accident, by rapidly redeploying resources and personnel. It is like an organism capable of interacting with and responding to changes in its environment: suppressing potential threats, seeking new resources, expunging waste material in its wake, and constantly adapting its configuration to suit the circumstances. The system functions not because it grows the value of its existing human capital but because it constantly harvests an influx of eager aspirants, replenishing its labor ranks with those amenable to a mobile and excessive regime of production. 
Critically, this protean apparatus both shapes and is shaped by the diverse and expansive relations that constitute it-it is therefore rife with contradictions and potential ruptures. So, while these interviews offer perceptive commentaries on structural changes that are affecting the everyday lives of media workers around the world, they raise equally important questions about the creative and financial limits of this mode of production. As our interlocutors speak eloquently about the pleasures of craft, we can't help but notice their reservations about the trajectories of change. Yet this tension between creativity and concern may ultimately prove productive. For the commitment to craftwork and collaboration not only provides solace for trying times, but may also provide the means to imagine and instigate alternatives in the future.

\section{LOCATING LABOR IN A GLOBAL CONTEXT}

The commentary above and the interviews that follow build on a substantial body of existing research in labor studies, cultural studies, and political economy. It is therefore essential to situate the propositions above in a broader historical and analytical context in order to appreciate the distinctive characteristics of screen media labor as well as continuities with other forms of industrial labor.

Historically, researchers point to the Reagan-Thatcher era as a tipping point in labor relations, as neoliberal principles of deregulation and privatization provided the intellectual foundation for a political movement that opened the door to corporate mergers and a foreign policy agenda premised on free trade. Seizing the opportunity, many companies shifted their manufacturing operations to low-wage nonunionized countries, creating a new international division of labor (NIDL) that allowed them to realize cost economies and counter the strength of unionized labor in the industrial societies of the West. ${ }^{12}$

As major manufacturers departed for distant locales, it tore apart the social and political fabric of working-class communities. It also created a transnational labor market that severely diminished the bargaining power of organized labor and attenuated the ability of governments to act as intermediaries. Countries that resisted this neoliberal agenda were abandoned in favor of more receptive locales where governments either acquiesced or actively colluded with transnational corporate interests. ${ }^{13}$ These changing structural conditions profoundly affected the everyday lives of workers everywhere. Societies in the Global North experienced a dramatic loss of manufacturing jobs, and union membership declined precipitously. Meanwhile, in developing societies, millions of new jobs appeared, but working conditions were grim. Lacking union representation, workers toiled long hours in often dangerous conditions for very low wages.

In the media industries, deregulation allowed companies to bulk up into vast conglomerates that expanded their reach to the far corners of the globe. Trade journals and the popular press exuberantly extolled the virtues of these 
developments and anticipated a future of robust growth. ${ }^{14}$ Other high-skill industries were booming as well, including software, biotech, and finance. In response to growing public concern about the loss of blue-collar jobs in the Global North, policymakers responded by pointing to the burgeoning "information economy" or "creative economy" as the logical trajectory for postindustrial societies, conjuring a future of high-wage jobs for urban dwellers and low-cost goods shipped in from manufacturers abroad. ${ }^{15}$

In Britain, which had been ravaged by deindustrialization, policymakers proved to be especially keen proponents of the creative economy, seeing it as a sector that could foster economic and social renewal. By offering subsidies and training programs within the context of a larger campaign to rebrand the nation as "Cool Britannia," the government sought to harness new sources of innovation and entrepreneurialism. Growth in the creative sector would arguably replace jobs and regenerate regions devastated by the loss of traditional industry. Soon, other countries and cities joined the game with their own creative industries policies, often seeking to attract screen media productions from foreign sources. ${ }^{16}$

Responding to these new enticements, Hollywood-which had been shooting feature films in distant locales since its inception-began to scale up its investment in mobile production. Producers sought out localities across North America and Europe, attracted by favorable exchange rates, lower labor costs, untapped infrastructure, and, most significantly, government subsidies and tax rebates. For instance, in the 1990s, Canadian exchange rates made it possible to trim production costs by almost 10 percent, while exchange rates in Prague (alongside the generally lower costs for goods and services) allowed producers to cut production budgets by a third. As the competition escalated, Louisiana, New York, and Georgia offered subsidies so generous that industry insiders impishly began to describe them as "big bags of cash." In addition to subsidies and incentives, Britain trumpeted its rich pools of talent in theater, advertising, and television; countries like Australia, the Czech Republic, Germany, Hungary, and Italy invested heavily in new or refurbished production facilities; and New Zealand and parts of Asia ramped up their postproduction services. Moreover, the Pinewood Group-a major facilities provider-branched out from its flagship studio complex in London to open soundstages in Wales, Atlanta, Toronto, Malaysia, and the Dominican Republic. Hollywood producers consequently found themselves coveted and courted around the world.

In their landmark volume Global Hollywood 2 (2005), Toby Miller et al. offer the most stringent critique of these transformations, arguing that compliant governments and labor organizations facilitated the extension of studio operations across a vast terrain of regions and locations. ${ }^{17}$ Seeking the "most favorable conditions," producers leveraged the competition to undermine labor protections and secure cost advantages, both at home and abroad. This dynamic gave rise to what 
the authors call a new international division of cultural labor (NICL), which has had deleterious effects on screen media wages and working conditions worldwide.

While this analysis provided timely insights regarding the broad structural transformations taking place, it too easily conflated film and television work with assembly-line labor and treated creative artifacts as industrial commodities. In doing so, it lost sight of the highly socialized nature of screen media production and tended to gloss over the more localized, everyday experiences of the craft workers themselves. As a political economy operating at a high level of abstraction, it failed to account for the diverse ways that employees-individually or collectivelynegotiate, contest, or even understand the structural changes affecting their workday practices. In other words, if screen media work has really become that bad, why do highly motivated, exceptionally skilled, and relatively advantaged workers subject themselves to such severe exploitation?

In fact, policy deliberations about cultivating creative economies have generally revolved around labor practices that are difficult to routinize. It therefore has been argued that creativity flourishes in flexible and informal working environments, allowing workers to pursue their passions, free from the monotony of the factory floor. This often involves short-term contract labor, but policymakers suggested that this form of casualization was a natural fit for the bohemian lifestyles of highly skilled workers aiming to control their professional destinies.

Yet the line separating autonomy from precarity proved to be a tenuous one, as contingent and irregular employment patterns started to define the general working conditions in many industries around the world..$^{18}$ Unlike media makers or designers, laid-off factory workers and underemployed youth found it difficult to take solace in the liberty of bouncing from job to job. Consequently, organized resistance to corporate abuses began to mount, punctuated by dramatic mass demonstrations at the 1999 meeting of the World Trade Organization. Around this time, labor studies began to shift attention from broad structural issues such as hypermobility and globalization (the NIDL) to more specific investigations into the ways that informality and precarity have upended workers' lives and workplaces. ${ }^{19}$ British academics - often working across the fields of cultural studies, critical sociology, and policy studies - have generated insightful critiques of the normative conditions of creative labor, examining how workers in a range of creative sectors balance their aspirations for creative autonomy with the pressures and uncertainties of casualized labor. ${ }^{20}$

Moreover, media studies research began to show that workers in the creative economy were not doing as well as imagined, especially in digital media, where the start-up culture of Silicon Valley had become a model for the sector as a whole. According to legend, dot-com employees endure long hours and modest wages in return for stock options that promise lavish returns if the company develops a product that catches the attention of investors and consumers. In fact, however, 
few workers hit the jackpot. Instead, most contract programmers and software developers migrate from project to project and from firm to firm. But given the booming demand for their services, many find it easy to land jobs, allowing them to work for a stretch and then take an unpaid break for personal projects or travel adventures. Researchers found that they prize this flexibility, but that the imagined material rewards have often proven elusive.

For their part, companies value the youthful passion of these employees and their willingness to put in long hours. By tricking out the workplace with trendy furniture, foosball tables, and other supposed diversions, employers have been able to command intense and extended bouts of labor during periods leading up to a product launch or upgrade. Inspired by industry leaders like Yahoo! and Google, tech companies have tried to obscure the boundaries between work and play, both to attract the very best creative talent and to make it unnecessary for them to leave the work/play-ce. ${ }^{21}$ This ethos of bohemianism and entrepreneurialism in the tech industry has rippled out into other sectors of the economy. Workers now sustain themselves on reputational capital and professional networks of trusted colleagues. ${ }^{22}$

Although these transformations seemed responsive to workers' desires to escape the drudgery of industrial routine, they fostered new forms of exploitation that allowed employers to evade responsibilities - for health care, retirement, paid vacation, and childcare-that industrial unions had struggled to put in place. ${ }^{23}$ Informality takes an even more distinctive toll on female workers, who are often excluded from the homosocial rituals of the workplace. It furthermore poses a challenge to those with domestic duties and care responsibilities, roles that disproportionately fall on the shoulders of women. ${ }^{24}$ Moreover, subtle forms of racial and gender discrimination tend to grow more troublesome in environments that lack formal institutions and protocols for representing worker grievances. Since unions are considered antithetical to flexible labor relations, workers have discovered that informality can prove to be a breeding ground for new forms of inequity and laddish behavior.

Consequently, the promise of the creative economy has proven to be a mixed blessing. ${ }^{25}$ And the trend toward informalization in the workplace has paradoxically been twinned with the formalization of media institutions around the world via marketization and conglomeration. Another paradox involves the hyperconcentration of corporate power during an era when media production became more decentralized via outsourcing, subcontracting, and the exploitation of amateur talent. ${ }^{26}$ Digital technologies have further eroded job categories and work routines, as traditional responsibilities have been delegated to "multimedia specialists" in various parts of the world who perform similar tasks but do so outside the jurisdiction of unions and regulations. ${ }^{27}$

Today, conceptions of creative labor often extol the virtues of individual enterprise and entrepreneurialism in the casual environs of the "gig economy," an 
increasingly common employment relationship in which the risks of both labor and capital are displaced onto individual workers. ${ }^{28}$ The current zeitgeist embraces the image of the autonomous professional who works from his or her own home, furnishes his or her own assets, and leverages new technology and mobile devices to facilitate more flexible and "unfettered" work arrangements. And yet the presumptions don't easily translate to screen media production, where workers try to reconcile contradictory ambitions for flexibility with enduring desires for structural benefits and representation. Craft laborers express frank concerns about the impact of these new management regimes on the creative components of film and television production. ${ }^{29}$

All of this puts tremendous pressure on screen media workers, both at home and abroad. Power remains in the hands of global conglomerates, and risk has been displaced onto vulnerable rank-and-file workers who are subject to tensions between formality and flexibility, both of which are endemic to a hypermobile mode of production.$^{30}$ Similar forces have taken a toll on unions, whose ranks have been diminishing precipitously as a consequence of deregulation and antilabor legislation. Wisconsin Governor Scott Walker's high-profile attacks on unions and collective bargaining are nightmarish examples of much broader historical developments. Laws and policies that used to protect workers have been twisted, if not abolished, in many parts of the world. ${ }^{31}$ Moreover, informality and entrepreneurialism in the creative sector have been embraced more generally by policymakers, much to the detriment of workers and unions. Contracts, competition, and scarcity furthermore undermine the value of collective consciousness, especially among young aspirants who are willing to work for minimal pay and benefits in exchange for autonomy and self-development..$^{32}$

Historically, the film and television industries have been a stronghold for organized labor. ${ }^{33}$ Yet our interviews bear witness to the various ways that employers are undoing many of the benefits of unionization: workdays have been extended, pensions have been reduced, wages have been slashed. Moreover, the dispersal of workers across an expanded geographic terrain threatens the very sociality of motion picture labor. And yet we were heartened to hear many of our interviewees say they are committed to turning back the tide, either through traditional labor organizations or grassroots efforts of their own.

We find resonances with this sentiment in "production studies" research that richly highlights the reflexive and meaning-making activities of screen media workers. ${ }^{34}$ This strand of research empirically engages with the working lives of below-the-line labor, grappling with the impact that technological change, productivity pressures, and financial scarcity have on traditional structures of craftwork and unionized labor. Many of these researchers offer nuanced assessments of the transformations taking place, but with few exceptions, ${ }^{35}$ they steer clear of linking their conclusions to the larger logics of global capital. Instead, they opt 
for more localized assessments of creative identities and workplace dynamics. Expressing reservations about causal arguments and reductive instrumentalism, these researchers tend to focus on capillary operations of power and complex terrains of struggle, rather than the larger structural forces reshaping media labor around the world.

Yet many of our interlocutors express an escalating concern about structural issues, often framing them with respect to abstract calculations made in distant corporate headquarters. At one level, this is an outcome of the growing physical and cultural distance between those who actually craft motion pictures and "the suits" who make life harder for workers on the set. On another level it's about the rising prominence of shareholder value as the preeminent principle of corporate governance, a process that some researchers refer to as financialization. These scholars contend that since the 1980s, public policy has fostered a "Copernican revolution" that has elevated the influence of the financial sector in almost every aspect of commercial enterprise. ${ }^{36}$ Not only has this shift encouraged corporate conglomeration, but it also has emphasized short-term profitability over foundational investments in research, development, and human capital.

Consequently, today's corporate managers find themselves responding to the relentless and mercurial demands of financial analysts, hedge funds, and institutional investors. Media workers often experience this trend in their dealings with studio executives and producers who privilege market logic over creative risk and novelty. Others say they confront incessant pressures to do more with less, showing little regard for the creative sacrifices or safety risks those directives entail. Time and again, our interview subjects provide evidence of escalating demands that seem insensitive to the realities of the workplace. These stories provide specific evidence of the human toll taken by conglomeration and mobile production, and they raise serious questions about the financial legerdemain that keeps the entire system in motion.

These voices of labor thus reveal the underlying complexities and contradictions of media production in the age of Global Hollywood. They furthermore demonstrate that many of these issues echo concerns expressed by a larger creative workforce that extends well beyond Southern California. Film and television workers around the world are now caught up, however unequally, in the mobile production apparatus of the major studios. Rather than publicity-friendly anecdotes by marquee celebrities, this collection of interviews offers nuanced observations from a range of perspectives, including a showrunner, a scriptwriter, a location scout; a grip, a musician, a makeup artist; an effects artist, a set designer, and a production manager. And although these stories are anchored in Los Angeles, they resonate with interviews in Atlanta, Dublin, Prague, and Vancouver.

In the end, we found a community of workers, from different locations and at different stages in their careers, equally vexed by globalization and conglomeration. 
Everyone who spoke with us pointed to the dramatic changes that have taken place in screen media over the last thirty years, connecting broad structural transformations to their more immediate concerns about workplace safety, teamwork, and creative practice, as well as family life, finances, and well-being. We were at the same time heartened by their affirmations that even in the face of adversity, they still have a sense of pride and fulfillment that is unmatched by most other industries. Yet these satisfactions exist in relation to unresolved tensions that permeate the conversations that follow.

\section{ABOUT THE ORGANIZATION OF VOICES OF LABOR}

We organized the collection into three sections: Company Town, Global Machine, and Fringe City. The first section refers to Hollywood's historic roots as a core component of the motion picture business. This section digs deep into the granular realities of everyday labor across a broad cross section of job categories, uncovering as well the tactics that workers employ to manage the seemingly incompatible pressures to innovate and economize.

The second section engages more directly with the spatial dynamics of film and television production to underscore the economic and political structures that are integrating distant locations into the studios' mode of production. Here the conversations highlight how globalization actually happens, focusing especially on the ways in which "mobility" becomes an embedded experience for many workers and workplaces around the world.

We close with a section on the visual effects sector. The stories shared by VFX artists, advocates, and organizers specifically illustrate how the industry today relies on marginal institutions to sustain its power and profitability. Grim working conditions at the "fringe" are the industry's canary in the coal mine, a powerful portent of what might happen if we allow the economic and political logics of the world's most powerful motion picture studios to run amok.

Collectively, we hope the interviews show how seemingly abstract concepts such as conglomeration, financialization, and globalization are useful tools for thinking critically about changes that are occurring in the motion picture business, but also more generally in our workplaces and culture at large.

\section{NOTES}

1. Robert W. McChesney, Telecommunications, Mass Media, and Democracy: The Battle for the Control of U.S. Broadcasting, 1928-1935 (New York: OUP, 1993); Nathan Godfried, WCFL, Chicago's Voice of Labor, 1928-70 (Chicago: University of Illinois Press, 1997).

2. Studs Terkel, ed., Working: People Talk About What They Do All Day and How They Feel About What They Do (New York: New Press, 1974). 
3. See John Thornton Caldwell's comments about the "war story" genre among media workers in his book Production Culture: Industrial Reflexivity and Critical Practice in Film and Television (Durham, NC: Duke University Press, 2008), but also in his preface to Production Studies, the Sequel!: Cultural Studies of Global Media Industries, ed. Miranda Banks, Bridget Conor, and Vicki Mayer (New York: Routledge, 2016), where he talks about his painting for the cover of the book.

4. David Bordwell, Janet Staiger, and Kristin Thompson, eds., The Classical Hollywood Cinema: Film Style and Mode of Production to 1960 (New York: Columbia University Press, 1985).

5. John Thornton Caldwell comments on self-theorizing and self-promotion in Production Culture.

6. Adopting André Bazin's observation about the prolific creativity of the integrated studio system of production, Thomas Schatz's acclaimed history is titled The Genius of the System: Hollywood Filmmaking in the Studio Era (New York: Pantheon, 1988).

7. Our interview strategy relied on snowball sampling to recruit a broad cross-section of screen media labor. We identified individuals through our own personal research networks and through the professional networks of the Media Industries Project at the University of California. Some individuals had no previous affiliation with us but we recruited them based on their reputations in the industry and relevance to the project. We aimed for diversity in medium, job category, seniority, and geographic location, but specifically targeted individuals whose work we perceived as most affected by the spatial operations and cost-cutting strategies of the major studios.

8. Michael Curtin and Kevin Sanson, eds., Precarious Creativity: Global Media, Local Labor (Oakland: University of California Press, 2016), DOI: https://doi.org/10.1525/luminos.10.

9. Henry Braverman, Labor and Monopoly Capital: The Degradation of Work in the Twentieth Century (New York: Monthly Review Press, 1974); Janet Staiger, "Dividing Labor for Production Control: Thomas Ince and the Rise of the Studio System," Cinema Journal 18, no. 2 (1979): 16-25; Frederick Taylor, Scientific Management (New York: Routledge, 2003); Max Weber, Economy and Society: An Outline of Interpretive Sociology (Berkeley: University of California Press, 1978).

10. Producers assemble above-the-line labor, usually directors, writers, and actors, as part of the development process to help secure financing for a film or television show. These costs are attributed to each individual "talent" identified by name in the budget. Below-the-line labor is calculated at the departmental, rather than individual, level as part of the technical costs of production. The terms "above-the-line" and "below-the-line" are derived from a line on budget sheets that distinguishes the production's development costs from its technical costs.

11. Matt Stahl, "Privilege and Distinction in Production Worlds: Copyright, Collective Bargaining, and Working Conditions in Media Making," in Production Studies: Cultural Studies of Media Industries, ed. Vicki Mayer, Miranda J. Banks, and John Thornton Caldwell (New York: Routledge, 2009), 54-67.

12. David Harvey, The Condition of Postmodernity: An Enquiry into the Origins of Cultural Change (New York: Blackwell, 1989); David Harvey, A Brief History of Neoliberalism (New York: OUP, 2005); Folker Frobel et al., The New International Division of Labour: Structural Employment and Industrialisation in Developing Countries (Cambridge, England: Cambridge University Press, 1980); Barry Bluestone and Bennett Harrison, The Deindustrialization of America: Plant Closings, Community Abandonment, and the Dismantling of Basic Industry (New York: Basic, 1982); Saskia Sassen, The Mobility of Labor and Capital (Cambridge, England: Cambridge University Press, 1988); Peter Dicken, Global Shift: Transforming the World Economy (New York: Guilford Press, 1998); Beverly J. Silver, Forces of Labor: Workers' Movements and Globalization since 1870 (Cambridge, England: Cambridge University Press, 2003).

13. Charles Tilly, "Globalization Threatens Labor's Rights," International Labor and Working-Class History 47 (1995): 1-23; Manuel Castells, The Information Age, vol. 7, The Power of Identity (Oxford: Blackwell, 1997); Fred L. Block, Postindustrial Possibilities: A Critique of Economic Discourse (Berkeley: University of California Press, 1990); Saskia Sassen, Globalization and Its Discontents: Essays on the New Mobility of People and Money, vol. 9 (New York: New Press, 1999). 
14. Less enthusiastic commentators, however, criticized the growing power of media conglomerates and the "Disneyfication" of cultures around the world. Ben H. Bagdikian, "The Lords of the Global Village," The Nation, June 12, 1989, 805-20; Edward S. Herman and Robert W. McChesney, The Global Media: The New Missionaries of Corporate Capitalism (London: Cassell, 1997).

15. John Howkins, The Creative Economy: How People Make Money from Ideas (New York: Penguin, 2001); Richard Florida, Cities and the Creative Class (New York: Routledge, 2005).

16. Toby Miller and Nitin Govil, Global Hollywood (London: BFI, 2001); Mike Gasher, Hollywood North: The Feature Film Industry in British Columbia (Vancouver: UBC Press, 2002); Serra Tinic, On Location: Canada's Television Industry in a Global Market (Toronto: University of Toronto Press, 2005); Ben Goldsmith and Tom O'Regan, The Film Studio: Film Production in the Global Economy (Lanham, MD: Rowman and Littlefield, 2005); Ben Goldsmith, Tom O'Regan, and Susan Ward, Local Hollywood: Global Film Production and the Gold Coast (St. Lucia, Australia: University of Queensland Press, 2010).

17. Toby Miller et al., Global Hollywood 2 (London: BFI, 2005). See also Susan Christopherson, "Behind the Scenes: How Transnational Firms Are Constructing a New International Division of Labor in Media Work," Geoforum 37 (2006): 739-51.

18. Andrew Ross, Nice Work if You Can Get It: Life and Labor in Precarious Times (New York: New York University Press, 2009).

19. Guy Standing, The Precariat: The New Dangerous Class (London: Bloomsbury Academic, 2011); Massimiliano Mollona, Made in Sheffield: An Ethnography of Industrial Work and Politics, vol. 5 (New York: Berghahn Books, 2009); Sian Lazar, "A Desire to Formalize Work? Comparing Trade Union Strategies in Bolivia and Argentina," Anthropology of Work Review 33, no. 1 (2012): 15-24; Patricia Fernandez-Kelly and Jon Shefner, Out of the Shadows: Political Action and the Informal Economy in Latin America (University Park: Pennsylvania State Press, 2006).

20. Mark Banks, The Politics of Cultural Work (Basingstoke, England: Palgrave Macmillan, 2007); David Hesmondhalgh and Sarah Baker, Creative Labour: Media Work in Three Cultural Industries (New York: Routledge, 2011).

21. Andrew Ross, No-Collar: The Humane Workplace and Its Hidden Costs (Philadelphia: Temple University Press, 2003).

22. For more on professional networks and reputational capital in the film industry, see Helen Blair, "You're Only as Good as Your Last Job': The Labour Process and Labour Market in the British Film Industry," Work, Employment and Society 15, no. 1 (2001): 149-69; Candace Jones, "Careers in Project Networks: The Case of the Film Industry," in The Boundaryless Career: A New Employment Principle for a New Organized Era, ed. Michael B. Arthur and Denise M. Rousseau (New York: Oxford University Press, 1996), 58-75. For more on the critical role trust plays in the creative industries, see Mark Banks et al., "Risk and Trust in Cultural Industries," Geoforum 31, no. 4 (2000): 453-64.

23. Andy C. Pratt and Rosalind C. Gill, "In the Social Factory? Immaterial Labour, Precariousness, and Cultural Work," Theory, Culture, and Society 25, nos. 7-8 (2008): 1-30; David Hesmondhalgh and Sarah Baker, Creative Labour; Gina Neff, Venture Labor: Work and the Burden of Risk in Innovation Industries (Cambridge, MA: MIT Press, 2012).

24. Angela McRobbie, "Reflections on Feminism, Immaterial Labour and the Post-Fordist Regime," New Formations 70, no. 1 (2011): 60-76; Rosalind Gill, "Cool, Creative, and Egalitarian? Exploring Gender in Project-Based New Media Work in Europe," Information, Communication, and Society 5 , no. 1 (2002): 70-89; Rosalind Gill, "Inequalities in Media Work," in Behind the Screen: Inside European Production Cultures, ed. Petr Szczepanik and Patrick Vonderau (New York: Palgrave, 2013): 189-205.

25. Mark Banks and David Hesmondhalgh, "Looking for Work in the Creative Industries Policy," International Journal of Cultural Policy 15, no. 4 (2009): 415-30.

26. Ramon Labato and Julian Thomas, The Informal Media Economy (Cambridge, England: Polity, 2015); Tiziana Terranova, "Free Labor: Production Culture for the Digital Economy," Social Text 
63 (2000): 33-50; Vicki Mayer, Below the Line: Producers and Production Studies in the New Television Economy (Durham, NC: Duke University Press, 2011), especially pp. 66-100.

27. John T. Caldwell, "Breaking Ranks: Backdoor Workforces, Messy Workflows, and Craft Disaggregation," Popular Communication 8, no. 3 (2010): 221-26.

28. Sarah Kaine and Emmanual Josserand, "Workers Are Taking on More Risk in the Gig Economy," The Conversation, July 6, 2016, https://theconversation.com/workers-are-taking-on-more-risk-inthe-gig-economy-61797.

29. Mark Banks, "Craft Labour and Creative Industries," International Journal of Cultural Policy 16, no. 3 (2010): 305-21.

30. Susan Christopherson, "Beyond the Self-Expressive Creative Worker: An Industry Perspective on Entertainment Media," Theory, Culture, and Society 25, nos. 7-8 (2008): 73-95; Susan Christopherson, "Behind the Scenes"; Michael Storper and Susan Christopherson, "The Effects of Flexible Specialization on Industrial Politics and the Labor Market: The Motion Picture Industry," Industrial and Labor Relations Review 42, no. 3 (1989): 331-47.

31. Vincent Mosco and Catherine McKercher, The Laboring of Communication: Will Knowledge Workers of the World Unite? (Lanham, MD: Rowman and Littlefield, 2009).

32. For a general overview, see David Hesmondhalgh and Sarah Baker, Creative Labour, 222-26.

33. See for example David F. Prindle, The Politics of Glamour: Ideology and Democracy in the Screen Actors Guild (Madison: University of Wisconsin Press, 1988); Gerald Horne, Class Struggle in Hollywood: Moguls, Mobsters, Stars, Reds, and Trade Unionists, 1930-1950 (Austin: University of Texas Press, 2001); Denise Hartsough, "Film Union Meets Television: IA Organizing Efforts, 1947-1952," Labor History 33, no. 3 (1992): 357-71.

34. John Thornton Caldwell, Production Culture; Vicki Mayer, Miranda J. Banks, and John Caldwell, Production Studies: Cultural Studies of Media Industries; Miranda Banks, Bridget Conor, and Vicki Mayer, Production Studies, the Sequel!.

35. Vicki Mayer, Below the Line.

36. Gerald Davis, Managed by the Markets: How Finance Re-Shaped America (New York: OUP, 2009). 